This article has been accepted for publication in Journal Conflict, Security \&

Development, published by Taylor \& Francis

https://doi.org/10.1080/14678802.2019.1609762.

\title{
Gender and state-building conversations: the discursive production of gender identity in Kenya and Rwanda
}

\author{
Awino Okech \\ Centre for Gender Studies, School of Oriental and African Studies, London, UK \\ ORCID: https://orcid.org/0000-0002-2541-0992
}

\section{Contact}

Email: ao21@soas.ac.uk

\section{Note on contributor}

Dr. Awino Okech is a lecturer at the Centre for Gender Studies at School of Oriental and African Studies, London. Her teaching and research interests lie in the nexus between gender, sexuality and nation/state-building projects as they occur in conflict and post-conflict societies. Prior to her appointment at the Centre for Gender Studies, she contributed to knowledge production and transfer through an adjunct teaching position with the African Leadership Centre at King's College London where she co-convened the Gender Leadership and Society module as part of the MSc in Security, Leadership and Society.

\begin{abstract}
This article advances the conceptualisation of conversations on state-building by examining gendered discourses. By focusing on specific historical moments in Rwanda and Kenya, this article analyses how 'respectable femininities' and 'wayward sexualities' become the 'sites' where national and state politics are ritualised and where tensions resulting from nonhegemonic performances of both gender and sexuality are resolved. I argue that by examining sites of gendered cultural production, it is possible to trace how gendered tensions are enacted through localised practices and discursive mechanisms deployed to manage political differences and build solidarity within heterogeneous groups. The ritualisation and creation of ethno-national homogeneity as part of state-building conversations occurs at the expense of greater freedoms for women. Fundamentally this article posits that gendered cultural and
\end{abstract}


traditional norms are essential sites from which to map state-building conversations and should not be cordoned off to the realm of social and therefore excluded from the political. 
Keywords: Gender; state-building; masculinities; femininity; militarism; Kenya; Rwanda

\section{Introduction}

The trajectories of state-building in the African continent are complex and this is grounded in an uneven colonial process. The processes associated with the formation of new states invariably meant the disruption of existing modes of life and vast displacement that was often accompanied by slavery, plunder, genocide, warfare and rebellions. While there are debates about how much we can directly connect the ongoing economic, political and social challenges to the legacies of colonialism, it is important to acknowledge that European colonialism drew colonies into new relationships with their socio-economic and political frameworks. The process of European colonialism in building hegemonies of systems of knowledge, framing how we think about states and societies today, cannot therefore be ignored. While this article does not intend to rehearse the connection between colonialism, capitalism and neo-liberalism, it is fundamental to how we think about dominant theories of the state, on the one hand, and relationships within the state, on the other hand, including those that are gendered.

Drawing on the concept of conversation, this article advances some thoughts on conversations on gender, recognising that these are 'not restricted to structured, overt, verbal dialogues or exchanges between a variety of actors within society. Rather, the focus is on wide-ranging interactions which are often unstructured, unseen, inexplicit and violent'. ${ }^{1}$ By extending the notion of conversation beyond actions that occur through recognised methods in formal policy-making spaces, we can begin to centre excluded groups and actions that are significant but hitherto uncaptured in state-building discourses. Discussions on state-building often fail to account for the ways in which gender identities and resources are mobilised. Reflections about power and the actors involved in peace- and state-building processes either proceed from assumptions about gender relations as neutral or the negation of the active participation of certain citizens as political actors.

Often, the distinctions on which citizens are excluded are informed by class, race and gender, but in any configuration, women tend to be excluded. Understanding this exclusion through theories around policy-making in the state introduces some engagement with power, actors and institutions. Writing about political life in sub-Saharan Africa, Chazan et al. articulated what is evidently not unique to Africa, which is the fact that policies evolve out of a complex web of social forces, institutional settings and inter-personal relationships. ${ }^{2}$ 
Scholarship that has relied on suggesting African exceptionalism when it comes to the influence of the 'deep state' in public policy-making, often as evidence of rudimentary statebuilding, has been debunked by in-depth understandings of how 'formal lobbying structures' within 'developed democracies' play the same role that so-called informal powerful networks play in politics in the sub-Saharan context. ${ }^{3}$ The exception may lie in the 'regulation' of organised political interest groups, which becomes difficult to manage in a context where their influence is not formally acknowledged. Understanding the state and political life in post-conflict contexts must therefore situate the informal and formal social structures that evolve in competition and/or conflict with those presented by state actors. Primary amongst these considerations are the actors that surround policy-making structures within the state and therefore those that are isolated from them.

Fanon argued that political isolation - in his case focusing on rural producers - is shaped by a separation of interests, with policies pursued by those in power intended to promote the political disorganisation of the peasantry. ${ }^{4}$ Bates, reflecting on the political economy in rural Africa, noted that members of a single social group must first use the power of the state to compel them to pursue common interests. ${ }^{5}$ The need to access state trappings therefore provides the impetus for organising around their common interests. Both Fanon and Bates situate the different power dynamics at play in how excluded groups either respond to and/or engage with policy processes that frame their subalternity. Fanon's assertion about policy processes that are geared towards destabilising the organising capacities of sub-groups suggests a decision network characterised by a web of decisions taking place over a long period of time and extending far beyond the initial policy-making process. Policies are therefore changed not on merit but due to shifts in key actors who introduce different agendas. Due to patron-client relations that characterise political processes, actors often intercede to try and modify, delay or terminate the implementation of policy programmes considered to negatively affect the interests of their respective constituencies. ${ }^{6}$ The power of male actors is associated with their physical proximity to the heart of the national political process, therefore women as a constituency are relatively powerless because of their remoteness. Women's vulnerability to exploitative policies therefore rests in their distance from power, including the power to coerce. Yet, women remain in conversation with policy actors at the centre, often 'talking back' through covert means and experiences that are not insignificant for the state-building project. It is this nexus between policy-influencing and making by formal and informal actors as the site for building and/or negating power bases in state-building projects that this article considers. If the argument is that women's distance 
from power bases increases their isolation, can theorisations of policy-making account for the invisible gender conversations that entrench women's powerlessness and the gendered labour mobilised to frame them as political actors. I juxtapose two country case studies to highlight these gendered discourses in state-building projects and illustrate how attentiveness to these debates can shift how formal spaces interested in thinking about gender in the state do so.

\section{Why Rwanda and Kenya}

This is not a comparative study. In looking at Rwanda and Kenya, the goal is to draw attention to how gendered discourses emerge, evolve and take shape when conflict mobilised around ethnic identity results in violent outcomes. Both countries have had significant turning points in their sociopolitical history. For Rwanda, this is the genocide and post-genocide period from 1994, while in Kenya the 2007-2008 post-election crisis was a critical turning point. It is worth repeating that the events that led to the genocide and the post-election crisis in Rwanda and Kenya respectively have their roots in much longer historical trajectories, which this article will not delve into in any depth. However, for purposes of analysis, this article will use these moments as the basis for a discussion on the meaning of gendered labour in post-conflict settlements and state-building. This article focuses on militarisation and accompanying forms of militarised masculinities in redefining these gendered outcomes during the political junctures identified in the case studies. To do this, I examine the function of discourses in the production of gendered states and how this manifests in state and society narratives. The central argument is that in paying attention to speech acts, how they travel and the institutions that validate them, we trace how gender discourses make their way into policy positions and therefore re-inscribe conservative, powerless gender norms rather than advance the gender disruption created by conflict. Given the moments I focus on in these countries, the key question is which institutions are considered powerful in the circulation of gendered discourses and their uptake as legitimate narratives in the state-building process. ${ }^{7}$ I focus on violence as a regulatory mechanism and how this operates both discursively and practically, as well as the role of memory and truth/s, as critical to state-building narratives.

\section{Thinking gender and the state}

Feminist theorisations on gender and nation states foreground the duality of women and violence; where women represent a continuous and potential site of violence that is not only rooted in the context of 'war' but also exists outside of that framework. In situating a 
normalised zone (the home, the street, the work place) as an active site of violent conflict in the state, feminist scholars have destabilised the popularly held notion of peace and conflict as distinct realms. ${ }^{8}$ This is grounded in an understanding that violence is an important way through which gender and social difference is maintained to sustain the exploitation of women's reproductive and productive labour. ${ }^{9}$ Consequently, women as the carriers/bearers of collective identity and honour both personally and collectively face immense pressure when these collectivities are under threat. ${ }^{10} \mathrm{~A}$ variety of cultural, legal and political discourses and policies are deployed to construct the boundaries of the collective.

A central dimension to these policies is concerned with the 'genetic pool' of the nation, thus the control of marriage, procreation and, therefore, women's sexuality tend to be high on the nationalist agenda. ${ }^{11}$ Women's citizenship becomes an area of regulation because women occupy an insider/outsider position in relation to citizenship, which may be heightened by class but occurs across class strata. On the one hand, women will be included in the general body of citizens when politically expedient but, on the other hand, rules, regulations and policies specific to managing their citizenship will exist. ${ }^{12}$ Most states use both land and blood criteria to codify and practice citizenship rules. The privileging of blood in citizenship rules goes hand in hand with the masculinisation of descent. ${ }^{13}$ Therefore, the state will permit fathers, but not mothers, to pass citizenship on to their children and husbands, but not wives, to pass citizenship on to their spouses. It is this insider/outsider relationship to citizenship of the nation and state that explains how violence against women becomes an important patriarchal tool to both discipline and therefore forge gender identities. Examined in this way, we move away from a debate on inclusion to one that examines the conditions that generate gender difference and violence as critical to power.

In contexts where the mobilisation of sectional interests relies on ethno-nationalism, consolidation processes are closely linked to the ways in which sexual violence against women, but also sometimes against men, is deployed during violent conflict. Aggressive notions of masculinity, which are especially evoked in times of war and crisis, become fundamental features of 'hegemonic masculinity', even if they contradict the ideas and the practice of many men. The term 'hegemonic masculinity' developed by R.W. Connell refers to four basic patterns of how men deal with one another: hegemony, subordination, complicity and marginalisation. Men behave hegemonically if they exclude or subordinate women and 'lower-ranking' men, and ensure their own dominance by possession of weapons and the use of violence. ${ }^{14}$ Ratele's concept of ruling masculinity expands this conceptualisation, by using the categories of age and income, to examine the relationship of non-hegemonic males to 
reigning ideas of maleness. ${ }^{15}$ It is within this framework that understanding violence against men is useful.

State- and nation-building processes that redress gender inequalities require wideranging conversations about women's freedoms that not only focus on the dynamics generated by conflict but also address the factors that reorganise structures that position women as secondary to men. This also requires a concomitant conversation on the ways in which violent masculinities are produced and sustained before, during and after conflict. It is in this context that the vehicles through which gendered discourses are produced in the state become critical. Complementing feminist theories of the state, the notion of memory and truth is also critical to how we read discourse production in the case studies explored in this article.

\section{Memory and truth/s}

Scholars writing from different disciplinary traditions have explored the notion of memory and multiple truths as a route to understanding marginalisation and/or specific socio-political moments. Cohen and Atieno Odhiambo, reflecting on oral narratives and memory, argue that: '[it is not so much about] the power of "a truth", or "the truth" but rather a claim to truth' ${ }^{16}$ The circulation of 'truth' in everyday speech makes it less about how well something is argued, evidence offered or whether it happened but more about how readily and commonly it was spoken about. ${ }^{17}$ Musila advances the conceptual utility of rumour in the same vein as Cohen, arguing that rumour offers an influential genre of knowledge production, contestation and critique in African societies that challenges single-lens conceptions of credible knowledge. ${ }^{18}$ Advancing this function of power and discourse is Macharia's notion of political vernaculars in Kenya:

Political vernaculars name real issues, but they also manage how those issues are handled. [...] Instead, Kenya's dominant political vernaculars shepherd or funnel us into predictable ends, generating two related demands: that the bad thing stop and that the good thing continues. ${ }^{19}$

Put together these scholars illustrate the importance of power in the discursive and its function in achieving specific nation- and state-building objectives. Macharia's notion of political vernaculars is useful in examining the ways narratives become taken for granted within the Kenyan state leading to pre-determined outcomes and therefore possibilities. Cohen's and Musila's conceptualisation of the utility of rumour is useful in examining how 
stereotypes led to the escalation of gendered violence in the context of the Rwandan genocide. The section that follows focuses on how the ideas explored above have played out in nationand state-building conversations in Kenya and Rwanda.

\section{Gender, genocide and Rwanda}

Gallimore, writing on the Rwandan genocide, illustrates how gendered linguistic and historical norms were rewritten and reproduced as essential tropes to support the genocide. ${ }^{20}$ Rwanda's history is framed as a class struggle between Hutu and Tutsi communities, with the economic dominance of the Tutsis shaped by ownership of cattle, which are seen as a measure of wealth, as opposed to the Hutus as a farming community. However, these class differences were managed through systems of social and political mobility where access to capital was gained through practices such as Ubuhake - the process of acquiring cattle - or marriage to a Tutsi woman from a rich aristocratic family amongst others. ${ }^{21}$ The colonial experience altered the relationship between gender, social identity and social mobility, producing one in which the linkages between gender and the production of ethnic boundaries become more pronounced. The conversion of class distinctions into ethnic ones resulted in power supremacy tensions, capitalised on by the colonial powers, which crystallised on more than one occasion into a violent politics of the 'other'. Consequently, the rejection of mixed marriages between Hutu men and Tutsi women during the months preceding the 1994 genocide became an important part of this narrative. Jones in Gallimore notes how pregenocide mobilisation revived many colonial images of beauty attributed to Tutsi women and manipulated them to create a sexualised enemy to be demystified and punished by rape. ${ }^{22}$ This was evident in the 'Hutu Ten Commandments', published by the extremist journal Kangura, in which fear of the Tutsi woman was emphasised. Tutsi women therefore represented a permeable boundary that had the potential to infiltrate the Hutu. In part the commandments read:

\section{[...] consider a traitor any Muhutu who: marries a Tutsi woman; befriends a Tutsi} woman; employs a Tutsi woman as a secretary or a concubine. Every Muhutu should know that our Hutu daughters are more suitable and conscientious in their role as woman, wife, and mother of the family. ${ }^{23}$ 
Scholars writing about ritualised practices, of which marriage and sex acts form a part, indicate that rituals as concepts, and conceptual categories that comprise and organise knowledge, are neither abstract in nature nor independent of the body; instead, they are directly or indirectly embodied. ${ }^{24}$ The continual production and reproduction of 'culture' and 'tradition' through ritual practices occurs through social practices that are seen to define sociable beings. The body is therefore a site where 'the most minute and local social practices are connected to large-scale organisation of power'. ${ }^{25}$ The body therefore becomes a political field upon which power relations have an immediate hold: 'they invest it, mark it, train it, torture it, force it to carry out tasks to perform ceremonies, to emit signs ${ }^{, 26}$;

females are correctly seen as literally the entry point through which the pure content may be adulterated, while males are treated as pores through which the precious stuff may ooze out and be lost, the whole system being thereby enfeebled. ${ }^{27}$

If we apply this lens to the altered relationship between marriage and social mobility in Rwanda, marriage to a Tutsi woman was read as an act of treason and a rejection of one's Hutu identity. Douglas argues that symbols associated with sexual danger, in this case marriage across communities, mirror the hierarchy and symmetry that apply to larger social systems. ${ }^{28}$ Therefore, the same impulse to impose order that brings these rituals into existence can also be supported by continually modifying or enriching them. ${ }^{29}$

The Rwandan experience above illustrates the ways in which narratives that frame community memory and identity, which are embodied through practices named as 'culture' and 'tradition', can be mobilised towards various state-building processes. The manipulation of 'culture' is evident during moments of 'moral panic' or crises, particularly when community 'boundaries' are challenged. When a community faces an 'external' threat, internal solidarity is fostered. ${ }^{30}$ This internal solidarity is negotiated and solidified through women's bodies and their sexualities, leading to heightened vigilance and surveillance of reproduction, marriage, birth, sex and sexuality. Women's bodies and their control is key to maintaining the boundaries of the ethno-nation or of the state. Rwanda is not unique, in the sense that the use of extreme forms of sexual violence against women has historically formed an important part of genocidal practices in addition to greater controls that are placed on marriage across groups as well as the function of violence as a regulatory practice. 


\section{Gender and the post-election crisis in Kenya}

The goals of state-building in times of crisis often determine the nature of discourses and, therefore, the policies that follow to control women's bodies and freedoms. In Kenya, the mobilisation of marriage and children across ethnicity was used in two main ways. The first prominent way was during the post-election crisis in 2007, where individuals in mixed marriages felt that their security was at greater risk. During this period, myth, rumour, past and current history, were invoked as 'evidence' of the importance of visible, ethno-national boundaries. Legends such as Luanda Magere, ${ }^{31}$ and rumours around the 'risks' associated with mixed ethnic marriages, were used to justify why marriage to 'outsiders' must be avoided. Mixed marriages were framed as constituting a danger to the ethno-nation and women as a potential threat to the ethno-nation through the subversion evident when women exercise choice. The testimony below is illustrative:

A Luhya woman married to a Kikuyu was abandoned by her husband on 30 December [2007]. He returned two days later and threatened to kill her, and sodomise her, saying he regretted marrying a Luhya, he threw her belongings out of their house, and refused to let her see her children

Thou shall belong to your father's tribe. If your father is Giriama and Mother is Kisii, you are Giriama. If a woman who is, say, from Taita father and Pokomo mother is married to a man who is Embu, their kids shall be Embu. That not only makes sense traditionally in all cultures but also is the only natural way to preserve our tribes. ${ }^{32}$

The greater loss to the ethno-nation was cited in terms of being unable to rely on and mobilise progeny from such relationships towards the goal of the ethno-nation, as was shown by the 'outsider' woman's loyalty to 'her people'. Aversion to the 'outsider' woman is thus enforced by a control and surveillance discourse rooted in patriarchy and patriliny. The inability to control the gene pool through the introduction of a foreigner who cannot be trusted is informed by an ethno-nationalist narrative that can only be sustained through a false notion of 'purity'. Yet, the resolution of conflicts that arise from ethno-nationalism are also known to mobilise marriage and women's reproduction. As biological producers of children/people, women are also bearers of the collective within these boundaries. Often, their primary identities within these collectivities override those they have as women. ${ }^{33}$ 
The public discourse generated by the experiences above made it clear that patriarchal heterosexual systems would be the only route through which children would be conferred the full benefits of their ethno-nation. Attempts to expand the notion of the Kenyan nation in opposition to the ethno-nation were rejected. The fact that discursive and physical threats resulted in the rejection of a global Kenyan-ness at this moment of crisis is critical in a context where the constitution offers expanded citizenship rights to women. This means that a non-Kenyan man married to a Kenyan woman can acquire Kenyan citizenship and children borne out of these unions can also acquire dual citizenship. Legality was subverted in the public domain at a moment when corralling sectional interests was key. Policy positions that gave women specific rights that would destabilise narrow definitions of communities were easily quashed through a retreat to culture and tradition, which relies on homogeneity and patriarchy as the locus of power.

The resurgence of 'ethnicity' as an identity from which self-location occurred during Kenya's post-election crisis in 2007 heightened the need to 'defend the tribe' and associated markers and symbols of the ethnic group. Thus, debates about women's sexuality in general and reproduction specifically came into sharp focus. The political moment offered insight into how moments of crisis in Kenya's history have contributed to the resurgence of debates on women's sexuality and are subsequently mobilised towards ethno-national aspirations and agendas within the state. Given that ethno-nationalism is often mobilised around the fictions of 'purity' and 'homogeneity', during crisis regimes often retreat into 'conservative' definitions and reconstructions of masculinities and femininities. These moves are often an attempt to construct a homogeneous 'us' versus 'them' for purposes of political negotiation. The reassertion of 'culture' and rites, which are articulated as disembodied, free of gendered tensions and interpreted as localised practices become important vehicles to enforce this ethno-national homogeneity. Similarly, discourses are deployed ritualise political differences and build solidarity within what are always heterogeneous communities. The control of women's bodies at these moments becomes essential, since they are deployed towards the service of the nation. As such, questions have been raised about the possibilities of women being able to dissociate themselves from kinship and ethnic boundaries to coalesce into a force that is primarily shaped by their identity as women during post-conflict reconstruction processes. 


\section{Phallocracy and the state}

The production of model women and therefore femininities occurs alongside reifying very specific ideas about masculinity. In thinking about how we transform gender norms in statebuilding conversations, it is critical to examine the interaction between the construction of femininities and masculinities, and their effects on the performance of politics. Of interest here are the ways in which debates certain forms of masculinity become reified as central to political leadership. Alongside this is the production of violent masculinities in the periphery of the state. One of the prominent ways in which hetero-patriarchal male-centricity is evident in political leadership is through discussions about manhood. The association made between masculinity, manhood and politics has been a dominant feature of public speech acts of Kenyan politicians. While it can be argued that statements of this nature form part of the common rhetoric associated with electoral politics, their affirmation in popular discourses serve the purpose of producing them as evidence of a direct relationship between hegemonic masculinities and leadership, authority and control.

The circulation of statements such as Kama wewe ni dume (If you are a bull) references to uncircumcised men as 'unprepared' for leadership - as well as instances of forced circumcision during the post-election crisis form part of a larger process of producing violent heterosexual masculinities as key to state-building. ${ }^{34}$ There is a corollary between these utterances and the perceptions they enforce around women's leadership and the subsequent physical and verbal violence. Insinuations about sizes of manhood and whether they are circumcised or not form part of a broader narrative to infantilise men, distinguishing between 'men' and 'boys' and asserting cultural authority and power by invoking 'culturally specific practices' such as male circumcision as superior and symbols of hegemonic masculinity.

Violence, in serving a regulatory function, also contributes to normalising practices by categorising certain acts of violence as legitimate and others as illegitimate. The reliance on gender difference to produce these distinctions occurs through the acceptance of forced circumcision of men as forms of violence as invalid because it is male domination over other men. These acts therefore go un-reported and are not dealt with because it challenges reigning ideas about real men. Real men cannot be subjugated in such intimate ways. The connection between male circumcision and being a 'real man' is linked to male bonding practices that occur during circumcision rites of passage within some communities, which serve to affirm hegemonic masculinities - strong, virile, fearless with authority over 'weaker' men, boys and 
women. These ideas make their way into speech acts, which in turn shape sectional ideas about hegemonic masculinities.

One of the ways in which speech acts translate into the production of violent masculinities is through the existence of political militias, which is an important part of the narrative around regime politics and masculinities in Kenya. The rise of political militias can be influenced by three main factors: regime tactics to manage power; groups with political interests challenging a regime's inability to develop inclusive socio-economic programmes; and groups capitalising on structural weaknesses (such as weak policing and socio-economic disparities) to develop criminal economies often in collusion with the state and/or parallel to the state. When regimes mobilise political militias into their service, whether they are called youth wings of political parties or crime preventers, this mobilisation is framed as a resolution to unemployment and thus co-opts the political choices of young men. The evolution of groups such as Sabaot Land Defence Force and Mungiki represent and account for the expansive mobilisation of violence for political and economic gains through sophisticated structures across geographical zones in Kenya. Both groups illustrate the interplay between socio-economic grievances as a starting point for organising identity as a basis for mobilisation and their mutation into political brokers, with violence as a key determinant of the power that they wield within communities as well as with politicians.

There are risks associated with constructing poor, urban and/or rural men and the resolution of their marginality through the prism of violence, criminality and (in)security. Sustaining violent masculinities in this way has an impact on the production of young women's identities in these communities, which is framed by insecurity and fear of violence. Additionally, political elite develop ambiguous relationship with political militias characterised by either allowing the militia activities to go unfettered in exchange for their mobilisation capacity for political ends, such as the 2005-2006 referendum campaign. or crackdown on the militia activities. This ambiguity reaffirms rather than dismantles the production of dominant violent masculinities as important to conflict creation and/or resolution.

Finally, the fact that militaries remain the last bastions of hyper-masculinity is not in dispute. They use and maintain the ideological construction of gender in the definitions of 'masculinity' and 'femininity'. Women are widely cast in the role of 'the protected' and 'defended', often excluded from military service and almost always - whether in conventional or guerrilla armies - excluded from direct combat. This division - separating the protector from the protected, defender from defended - is crucial to both sexism and militarism. ${ }^{35}$ 
This article does not offer an analysis of efforts to democratise military governance and what that has yielded in terms of shifting attitudes towards women in these institutions. This is largely because feminist scholarship on gender and militaries is ideologically split on whether including women in an institution that is fundamentally framed by violence and coercion can in any way be liberatory for women and non-hegemonic men. ${ }^{36}$ I focus here on what exhibitions of militarised masculinities communicate to society about hegemonic masculinities, leadership and security. Macharia's notion of political vernaculars is useful in framing how discourses on security when attached to militarisation serve a broader disciplinary function. ${ }^{37}$ Security or securing the nation becomes a political lexicon that mobilises fixed debates that are either about securing rights and freedoms of the excluded or about protecting the nation from external threats. In both instances, demands that are cultivated by this political vernacular restrict the possibilities of imagining different ways of securing freedom and security.

Performances of militarised masculinity through military symbols are considered key signifiers of the relationship between the military forces and the state. However, it is the connection between military ideals of discipline, order and rank and the intersection between civilian forms of governance and the military that are important here, particularly in postconflict settings. These factors interact to produce a heightened sense of militarism in society, which is accompanied by increased resource allocation to military budgets as well as a blurring of the lines between the role of the military in national security and that of domestic security forces.

Since flag independence in 1963, Kenya has been governed by civilian leaders, thus making the distinction between the barracks and the Executive tidy, albeit complicated. Therefore, the regular appearance of the current president Kenyatta in military fatigues, as distinguished from ceremonial military wear, has raised questions about the separation of the military and the executive. This is largely informed by the fact that the military as an institution has a distinct culture that draws on symbols, which include dress and corporate culture, and relies on separation, evident in the distinction between ranks and a difference between disciplined forces and civilians anchored in their military training. These distinctions are important to the military's functioning. Daily military interaction is expressed, facilitated and regulated by symbols of the military culture. Examples include saluting as a gesture of respect and submission to military discipline, while uniforms act as symbols for identification and status amongst military personnel. 
The constitutional separation of the military and civilian control over military forces as part of democratic processes is also critical to the separation of functions. Kenyatta's insistence on dressing in military uniform conflates the idea of a civilian commander in chief of the armed forces and military symbolism associated with the monopoly of violence. In adopting military gear, Kenyatta clearly seeks to associate very specific forms power that are connected to the military's control of the instruments of coercion with his authority as a leader of the country. The political vernacular produced by these actions emphasize a link between military symbols and security provisioning whilst erasing the multiple layers of insecurity that are disconnected from territorial integrity. While the president's choice of dress can be considered inconsequential and non-impactful, it has been accompanied by a greater investment in a stronger security discourse, which foregrounded military- and security-related expenditure, as the framework to manage the internally generated weaknesses harnessed by Al Shabaab. ${ }^{38}$

Rwanda often presents a gender dilemma. On the one hand, if the symbol of equality is to be found in good laws and the representation of women in public office, then Rwanda has surpassed this goal. However, the progressive laws and policies that provide equal access to land and the robust provision of marriage equality is informed by the impact of the genocide on the Rwandese population that led to a higher population of women. The Rwandese president has publicly acknowledged that the pursuit of gender equality is based on a logic of maximising on citizens irrespective of gender. ${ }^{39}$ Yet the cases of Victoire Ingabire Umuhoza and Diane Rwigara are instructive. Both these women ran for presidency and both were incarcerated on charges of treason. It is important to note that strong-arm responses to male candidates have occurred too but what stands out here is the mobilisation of gendered ideas on morality that were specifically deployed against these women. These notions of morality are in seen in the publishing of nude photos in Rwigara's case to the criminal charges against the family as part of subverting political ambitions, which are known to harm women in public office more than men because of societal notions of women's respectability. ${ }^{40}$ Umuhoza, on the other hand, was the head of the United Democratic FrontInkingi opposition party. She was arrested in 2010 and charged with conspiracy to undermine the government as well as denying Rwanda's 1994 genocide and was sentenced to 15 years. ${ }^{41}$ She was released in 2018.

Rwanda's history of genocide influences to a great degree how the state-building process has occurred - specifically the control of the instruments of government. The presidency is organised around tight control of civic space, which is sustained by militarised 
masculinity. Militarised masculinity here refers to the mobilisation of norms that drive militaries such as deference to rank and authority, order, discipline and an acceptance that the use of force and violence are key to gendered order. This is applicable to men and women alike. From political repression, to national cleaning days, what one sees in Rwanda is the exercise of dominant hegemonic masculinity (keeping the history of violence in mind) whilst mobilising normative gender principles to resolve and manage a history where ethnonationalism has been mobilised to violent ends.

In considering how the production of hegemonic masculinities has an impact on resultant state policies and therefore the place of women and other non-hegemonic groups in any society, paying attention to national conversations on gender is key. These include: discourses that produce a distinction between boys and men as part of larger political rhetoric to assert male leadership; narratives that privilege cultural practices such as male circumcision as markers of male authority and the use of forced male circumcision during conflict; and political norms and practices that see the creation of political militias, often consisting of young male youth, framed as security providers or as a resolution to unemployment. These practices reinforce violence as a legitimate way in which maleness is understood in society and concomitantly how women and girls should interact with these forms of masculinity, which is often through fear and subordination. The production of these masculinities by the state are shaped by a stereotypical, collective consciousness that frames aggression and the propensity for violence as biological, with courage being attributed to men and passivity, peacefulness and motherliness to women. The projection of these as absolute models on both sides - soldier and statesman, on the one hand, and mother of the nation, on the other -sustain the deployment of youth as a category that describes young men as agents (with access to violence as a coercive tool) and young women as recipients of development to be protected. ${ }^{42}$ If men are using violence and other forms of rent-seeking as a route then what routes are young women using to deal with exclusion and in what ways does that reinforce traditional ideas of masculinity and femininity and with what effect? Understanding how power operates is therefore integral to situating legitimate and illegitimate forms of gendered violence, the identities they produce and their function in sustaining hetero-patriarchal state and society relations.

\section{Conclusion}


This article focussed on two case studies, Kenya and Rwanda, not necessarily to highlight correlations, draw comparisons and/or examine continuities around gender and state-building conversations. Rather, the intention was to examine what these case studies demonstrate about conversations of gender and state-building in moments of crisis. In both cases, discourses on gender identity are closely linked to the survival of the nation state and are therefore corralled around a set of cohesive discourses linked to purity and group survival. These discourses are enacted through culture, tradition and various forms of state and community-based violence, which serve as a regulatory tool. At the root of the regulatory discourses and the mobilisation of gender is a hetero-patriarchal state that arrogates the power to award and hold back full freedoms as part of this process. The arrogation of gendered state power is riddled with contradictions.

Women and girls are mobilised as mothers, child bearers and nurturers to contribute to de-radicalising young men and sustain peace. Yet, at the same time an environment in which public spaces occupied by women are constricted whether this occurs through attacks of women in public office, ${ }^{43}$ stripping women in the streets for "indecent" dressing, ${ }^{44}$ and most potently through the failure to fulfil the gender equality provisions in the constitution. These actions are demonstrative of how violence serves to discipline women through fear and keep them in traditional gender roles. The structural belief that women who have 'strayed' from their traditional roles should be violently guided back to their rightful place is implicit in these actions.

Attacks on women and girls do not occur in a vacuum. As the Kenya case demonstrated, the increasing criminalisation of young men on the margins the country and the class dynamics that shape the disposability of young men's lives heighten violent masculinities. The daily insecurity faced by women is justified by the acceptance that enacting violence is synonymous with providing security. This belief is evident in the support granted to security forces and the reduction in civilian oversight in resolving the Al Shabaab crisis in Kenya. That state violence against marginalised communities is deemed justifiable pervades public debate in Kenya and illustrates how deeply militarisation discourses are embedded and expand the state's surveillance and containment strategies. Consequently, the relationship between discourses and practices of violence, militarisation and peace is key to disrupting gendered conversations on nation- and state-building.

Finally, dominant responses that continue to place analytical value within structures (the law, parliament, human rights commissions) and the rights framework (through the constitution or national reconciliation processes) as the only way to think about state-building 
conversations are limited. Gender and sexuality contestations, whether through a focus on reproduction or respectable femininities, form the fulcrum for conversations, rumour, political vernaculars and re-inscribed truths around contested gendered identities and their place in the state. Approaches that are inattentive to the analytical opportunity evident in thinking about discourses and power as a route to developing effective policy do not begin to tackle the aspirations and the spaces where people retreat to 're-write identity'. These spaces, I argue, are represented by 'cultural practices' and, as Macharia notes, through political vernaculars that ring fence how progress, development and justice are framed, debated and therefore imagined in any state. ${ }^{45}$ Analytical blindness to these sites means that we do not begin to deal with how hetero-normativity, gendered identities and subjectivities are forged within specific contexts. The dissociation of sexuality, women's bodies and reproduction as core transmitters of the 'national' (ethnic) project 'reads' the tribe in abstraction from the mechanisms that reinforce and sustain it. Tribe becomes political rather than a social construct that is deeply reliant on gendered labour to survive. That the mobilisation of gendered labour is political becomes subsumed in vernaculars that situate the political as only existing as 'realpolitik'. Finally, these conclusions can be translated into laws and policies but they predominantly live in the realm of the discursive, the everyday practices which are embodied and/or made visible by national debates about the place of women and men in the state and its future. It is in the quotidian that the rigidity and mobility of gender ideas acquire life and/or are destabilised.

\section{References}

Associated Press, 2018. 'Rwandan Opposition Leader, 2,100 Others Walk Free from Prison', 15 September. Available at: https://www.voanews.com/a/rwandan-opposition-leader2100-others-walk-free-from-prison/4572858.html. [Accessed 16th April 2019]

Bates, Robert, 1983. Essays on the Political Economy of Rural Africa. Cambridge University Press, Cambridge.

Bell, Catherine., 1992. Ritual Theory, Ritual Practice. Oxford University Press, New York.

Brandon, Hamber, Paddy Hillyard, Amy Maguire, Monica McWilliams, Gillian Robinson, David Russell and Margaret Ward (eds.), 2006. 'Discourses in Transition: Reimagining Women's Security'. International Relations 20 (4), 487-502.

Burton, Antoinette. (ed.), 1999. Gender, Sexuality and Colonial Modernities. Routledge, New York.

Chazan Naomi and Timothy Shaw, 1998. Coping with Africa's Food Crisis. Lynne Rienner Publishers, London. 
Cockburn, Cynthia, 2001. The Space Between Us. Negotiating Gender and National Identities in Conflict. Zed Books, London.

Cohen, David William and E.S Atieno Odhiambo, 2004. The Risks of Knowledge: Investigations into the Death of the Hon. Minister John Robert Ouko in Kenya, 1990. Ohio University Press, Athens, OH.

Commission of Inquiry into the Post-Election Violence (CIPEV), 2008. Report of the Commission of Inquiry into the Post-Election Violence. The Government Printer, Nairobi.

Connell, Robert, 1995. Masculinities. Polity Press, Cambridge

Douglas, Mary, 2002. Purity and Danger: An Analysis of the Concepts of Pollution and Taboo. Routledge, London.

Enloe, Cynthia, 2000. Maneuvers: The International Politics of Militarizing Women's Lives. University of California Press, Berkeley, CA.

Fanon, Frantz, 1968. The Wretched of the Earth. Grove Press. New York.

Gallimore, Rangira Béa, 2008. 'Militarism, Ethnicity, and Sexual Violence in the Rwandan Genocide'. Feminist Africa 10, 9-29.

Gender and Human Security Network, 1999. 'Manifesto'. Available at: http://gwynkirk.com/pdf/gender_and_human_sec.pdf [Accessed 13 February 2018].

Jones, Bruce, 2001. Peacemaking in Rwanda: The Dynamics of Failure. Lynne Rienner, Boulder, CO.

Joseph, Souad, 1999. 'Descent of the Nation: Kinship and Citizenship in Lebanon'. Citizenship Studies 3(3), 295-318.

Kandiyoti, Deniz, 1991. 'Identity and its Discontents: Women and the Nation'. MILLENIUM: Journal of International Studies, 20(3), 429-43

Kangura, 1990. No. 6. "The Ten Commandments": Available at: http://www.rwandafile.com/Kangura/pdf/k06,23,26,28,33,40,41,46,59.pdf

Lombard, Nancy (ed.), The Routledge Handbook of Gender and Violence. Routledge, London.

Macharia, Keguro, 2016. 'Political Vernaculars: Freedom and Love'. Available at: https://thenewinquiry.com/political-vernaculars-freedom-and-love/. [Accessed $16^{\text {th }}$ April 2019

Mama, Amina and Margo Okazawa-Rey, 2012. 'Militarism, Conflict and Women's Activism in the Global Era: Challenges and Prospects for Women in Three West African Contexts'. Feminist Review 101 (1), 97-123. 
McClintock, Anne, 1995. Imperial Leather: Race, Gender and Sexuality in the Colonial Contest. Routledge, New York.

Mugisha, Ivan, 2019. 'Rwigara Welcomes Decision to Drop Appeal, Vows to Continue with Her Rights Crusade'. The East African. January $9^{\text {th }} 2019$. Available at: https://www.theeastafrican.co.ke/news/ea/Rwigara-welcomes-decision-to-dropappeal/4552908-4927390-v8tuu3z/index.html [Accessed 16th April 2019]

Musila, Grace, 2017. 'Navigating Epistemic Disarticulations'. African Affairs 116 (465), 692704.

Mwai, Collins, 2018. 'Society Benefits from Gender Equality - Kagame'. The New Times Rwanda. July $1^{\text {st }}$ 2018. Available at: https://www.newtimes.co.rw/africa/societybenefits-gender-equality-kagame [Accessed 16th April 2019]

Okech, Awino, 2015. 'Dealing with Asymmetrical Conflict: Lessons from Kenya'. Special Issue of Strategic Review of Southern Africa 37(1) 53 - 74.

Okoth, D., 2006. 'Luanda Magere: A Legend Whose Spirit Lives On'. Available at: http://www.afroarticles.com/article.../Luanda-Magere--A.../4582 [Accessed February 2018].

Olonisakin, 'Funmi, Alagaw Ababu Kifle and Alfred Muteru, Forthcoming. 'Shifting Ideas of Sustainable Peace Toward Conversations in Statebuilding'. Unpublished paper.

Oyugi, Walter, Peter Wanyande and C. Odhiambo-Mbai (eds.), 2003. The Politics of Transition in Kenya: From KANU to NARC. Heinrich Boell, Nairobi.

Ratele, Kopano, 2008. 'Analysing Males in Africa: Certain Useful Elements in Considering Ruling Masculinities'. African and Asian Studies 7 (4), 515-536.

Star Newspapers, 2016. 'Gideon Moi is Uncircumcised, Says DP Ruto', 22 February. Available at: http://www.the-star.co.ke/news/2016/02/22/gideon-moi-is-uncircumcised-says-dpruto_c1298987 [Accessed 13 February 2018].

Star Newspapers, 2016. 'Kabogo in Court for "Insulting” Raila Odinga', 6 August. Available at: http://www.the-star.co.ke/news/2016/08/06/kabogo-in-court-for-insulting-railaodinga_c1398954 [Accessed 13 February 2018].

Thomas, Clive, 2001. Political Parties and Interest Groups: Shaping Democratic Governance. Lynne Reinner Publishers, Boulder, CO.

White, Louise, 2001. "True Stories: Narrative Event, History and Blood in the Lake Victoria Basin" in White, Louise, Stephan F. Miescher, Stephan Miescher, David William Cohen (eds). African Words, African Voices: Critical Practices in Oral History. Indiana University Press, Bloomington. 281-304

Yuval-Davis, Nira and Flora Anthias (eds.), 1989. Women-Nation-State. Macmillan, London. 
Yuval-Davis, Nira. 1997. Gender and Nation. Sage, London.

\section{Endnotes}

${ }^{1}$ See Olonisakin et al., 'Shifting Ideas of Sustainable Peace'.

${ }^{2}$ Chazan et al., Coping with Africa's Food Crisis, 71.

${ }^{3}$ See Thomas, Political Parties and Interest Groups.

${ }^{4}$ Fanon, Wretched of the Earth, 150

${ }^{5}$ Bates, Essays on the Political Economy.

${ }^{6}$ See Oyugi et al., The Politics of Transition in Kenya.

${ }^{7}$ Foucault, History of Sexuality.

${ }^{8}$ See Brandon et al., 'Discourses in Transition', 488.

${ }^{9}$ See Lombard, The Routledge Handbook of Gender and Violence

${ }^{10}$ Yuval-Davis, Gender and Nation, 45.

${ }^{11}$ Ibid., 22.

${ }^{12}$ Ibid., 24.

${ }^{13}$ See Joseph, Descent of the Nation.

${ }^{14}$ Connell, Masculinities.

${ }^{15}$ See Ratele, 'Analysing Males in Africa'.

${ }^{16}$ Cohen and Atieno Odhiambo, The Risks of Knowledge, 265.

${ }^{17}$ White, True Stories, 286.

${ }^{18}$ Musila, 'Navigating Epistemic Disarticulations', 692.

${ }^{19}$ Macharia, 'Political Vernaculars'.

${ }^{20}$ Gallimore, 'Militarism, Ethnicity, and Sexual Violence', 13.

${ }^{21}$ Ibid., 13-14.

22 Jones, Peacemaking in Rwanda, 18.

${ }^{23}$ Kangura, 6-8.

${ }^{24}$ Bell, Ritual Theory, Ritual Practice, 95.

${ }^{25}$ Ibid., 202.

${ }^{26}$ Ibid., 202.

${ }^{27}$ Douglas, Purity and Danger, 156.

${ }^{28}$ Ibid., 4.

${ }^{29}$ Ibid., 5 .

${ }^{30}$ See Burton, Gender, Sexuality and Colonial Modernities; Kandiyoti, 'Identity and its Discontents'; McClintock, Imperial Leather; Yuval-Davis and Anthias, Women-Nation-State.

${ }^{31}$ Luanda Magere is the story of a Luo hero who married a Nandi woman who betrayed him by revealing to his tribe where his power lay, which was in his shadow and not his body (see Okoth, 'Luanda Magere').

${ }^{32}$ CIPEV, Report of the Commission of Inquiry, 246

${ }^{33}$ See Yuval-Davis and Anthias, Woman-Nation-State.

${ }^{34}$ Star Newspapers, 'Gideon Moi is Uncircumcised'; and 'Kabogo in Court'.

${ }^{35}$ See Mama and Okazawa-Rey, 'Militarism, Conflict and Women's Activism'.

${ }^{36}$ Enloe, Maneuvers; Gender and Human Security Network, 'Manifesto'.

${ }^{37}$ See Macharia, 'Political Vernaculars'.

${ }^{38}$ See Okech, 'Asymmetrical Conflict and Human Security'.

${ }^{39}$ Mwai, 'Society Benefits from Gender Equality'.

${ }^{40}$ Mugisha, 'Rwigara Welcomes Decision'.

${ }^{41}$ Associated Press, 'Rwandan Opposition Leader'. 
${ }^{42}$ Cockburn, The Space Between Us.

${ }^{43} \mathrm{https}: / /$ femnet.wordpress.com/category/gender-based-violencebodily-integrity/page/8/

${ }^{44} \mathrm{https}$ ://www.equalitynow.org/action-alerts/stop-violent-attacks-women-mydressmychoice ${ }^{45}$ See Macharia, 'Political Vernaculars'. 